Provided for non-commercial research and education use. Not for reproduction, distribution or commercial use.

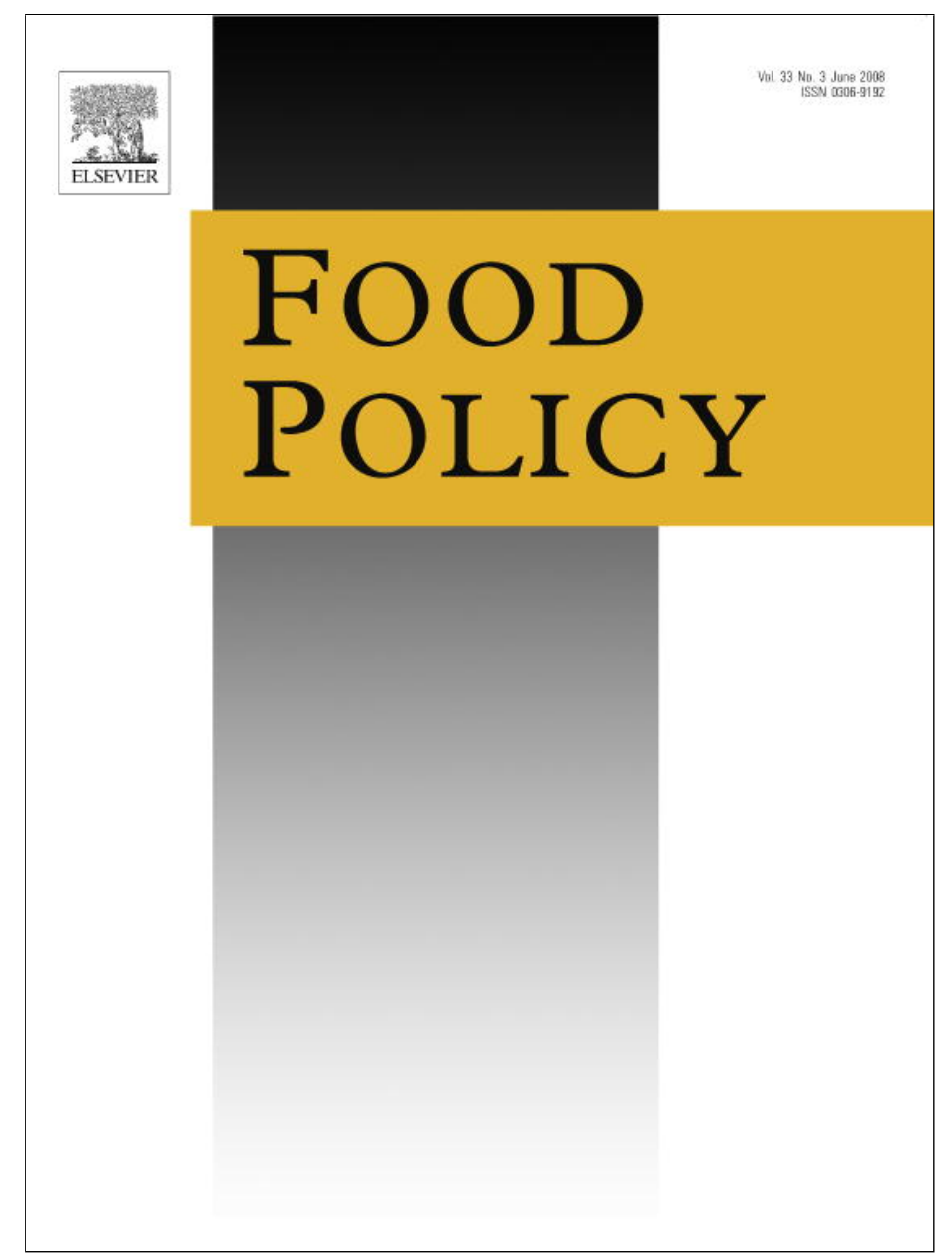

This article appeared in a journal published by Elsevier. The attached copy is furnished to the author for internal non-commercial research and education use, including for instruction at the authors institution and sharing with colleagues.

Other uses, including reproduction and distribution, or selling or licensing copies, or posting to personal, institutional or third party websites are prohibited.

In most cases authors are permitted to post their version of the article (e.g. in Word or Tex form) to their personal website or institutional repository. Authors requiring further information regarding Elsevier's archiving and manuscript policies are encouraged to visit:

http://www.elsevier.com/copyright 


\title{
Food insecurity, poverty and the Malawian Starter Pack: Fresh start or false start?
}

\author{
Jane Harrigan * \\ Department of Economics, School of Oriental and African Studies, The University of London, Thornhaugh Street, Russell Square, \\ London WC1H OXG, United Kingdom
}

Received 29 November 2005; received in revised form 13 September 2007; accepted 20 September 2007

\begin{abstract}
Chronic food insecurity and chronic poverty are closely related in Malawi. Since independence in 1964 national food security has been a key policy objective. However, until the 1990s less emphasis was placed on the household dimensions of food security and its links with chronic poverty. In the last decade a number of initiatives have been used in Malawi to tackle the issue of household food insecurity. One of the most controversial has been the Starter Pack programme launched in 1998. Initially consisting of a free handout of packs of improved maize seed, legumes and fertiliser to every small holder farm household in Malawi the scheme, under donor pressure, was subsequently scaled down to become a form of targeted social safety net programme. This paper analyses the strengths and weakness of both the original programme and its scaled down version and assesses the reason for the considerable opposition to the programme from Malawi's donor community. Although Starter Pack is no longer operative in Malawi the Malawian experience is used to derive lessons for other countries where household food insecurity is an important dimension of chronic poverty.
\end{abstract}

(C) 2007 Elsevier Ltd. All rights reserved.

Keywords: Food security; Malawi; Starter pack; Poverty alleviation

\section{Introduction}

Chronic poverty is closely linked with both chronic and transitory food insecurity in Malawi. Malawi is both one of the poorest countries in the world and is densely populated. This means that many farm households cannot afford inputs and do not have adequate land for their subsistence food requirements. But as a landlocked country with poor transport infrastructure, imports of the bulky staple food crop maize are expensive such that the $80 \%$ or so of households who are net food consumers often cannot access maize in the market at affordable prices. The relationship between chronic poverty and food insecurity is bi-directional and can often lead to the establishment of a vicious circle. The chronically poor are often the most vulnerable

\footnotetext{
* Tel.: +4402078984537.

E-mail address: jh66@soas.ac.uk
}

to food insecurity - particularly exposed to food insecurity hazards as well as having limited coping mechanisms to deal with such hazards. Food insecurity in turn can further deepen poverty, not just in terms of negative nutritional effects on health and livelihoods but through the use of coping mechanisms such as asset sales which make it harder for families to lift themselves out of the poverty trap.

As a result of the above, food security is a persistent preoccupation of all those involved in Malawi's development efforts. Government, donors and non-governmental organisations (NGOs) all acknowledge that a large proportion of Malawi's population remains chronically food insecure and that until this issue is addressed the broader process of development will be thwarted. Likewise, many agree that past government and donor efforts to overcome chronic food insecurity have failed to bring about a significant improvement (Oygard et al., 2003, p. v; World Development Movement, 2002, p. 10). Here, however, consensus 
seems to end. Within both the donor and government communities a spectrum of views exists as to how Malawi should best tackle the issue of chronic food insecurity.

This paper provides an overview of food security options for Malawi from both a theoretical and historical perspective. Within this context it analyses the role of the Starter Pack initiative, which was launched by the Malawi government in 1998. Starter Pack consisted of a free handout of a small pack of improved maize seed, legumes and fertiliser to all small holder households in Malawi. The initial pack was enough to cultivate 0.1 ha of maize. Although the principle aim was to introduce farmers to improved technologies in a risk free manner as a production boosting initiative it was also hoped that the pack would improve food security. Food security was expected to be improved both by increasing the number of months the average family could feed itself and, as a result, reducing demand for food in the market so as to reduce the consumer price. The scheme however, attracted considerable criticism from Malawi's donor community and as a result under went a number of transformations. The aim of this paper is to assess the Starter Pack experience to draw lessons for food security and more general agricultural development strategies of both Malawi and other countries in the region.

\section{Food insecurity and poverty in Malawi}

An extremely low GDP per capita of $\$ 160$ combined with one of the most unequal income distributions in the world - a gini coefficient of 0.65 in the late 1990s, surpassed only by Brazil and Namibia - means that poverty is both pervasive and deep in Malawi. Estimates suggest that $64 \%$ of Malawians live in poor households and $36 \%$ in ultra-poor households ${ }^{1}$ (Government of Malawi, 2004). Given that the food share in the poverty line is over $80 \%$ (see Table 1) it can readily be assumed that poverty and food insecurity go hand in hand in Malawi. The Forum for Food Security in Southern Africa has made the argument convincingly:

"Given the high share of food in the poverty line, the $36 \%$ of the population (equating to over 4 million people) below the ultra poverty line can be assumed to be chronically food insecure: regularly unable to access sufficient food. Those below the poverty line but above the ultra poverty line (a further $28 \%$ of the population equating to 3.3 million people) are likely to experience transitory food insecurity, i.e. to be unable to access adequate food all year round" (FFSSA, 2004).

In other words over half of Malawi's nearly 12 million population are both poor and food insecure.

The close links between poverty and food insecurity in Malawi can be explained by a variety of factors. Around

\footnotetext{
${ }^{1}$ Based on the 1997-1998 Malawian Integrated Household Survey using a poverty line of MK11 a day (which is close to the standard dollar a day measure) (Government of Malawi, 2004).
}

$85 \%$ of the population work in agriculture, the majority being small holders producing first and foremost maize for home consumption. However, intense population pressure means that the average farm-holding for small holders is less than 0.8 ha. Even with good maize yields, this is inadequate to produce enough food to feed the average family throughout the year. Reliance on rain-fed agriculture with an increasingly variable single season rainfall, plus extensive soil degradation over the past two decades, means that maize productivity has been declining as has maize production per capita. This has translated into declining calorie intake per capita. Although maize production has trended upwards over the last two decades (see Fig. 1), population growth of $2 \%$ per annum has led to a decline in per capita maize availability. For example, between 1979 and 1989 maize production per capita fell from $244 \mathrm{~kg} /$ per capita to $193 \mathrm{~kg} /$ per capita whilst by 2003 it had fallen to $184 \mathrm{~kg} /$ per capita. Low productivity is compounded by the high cost of imported fertiliser, particularly since the removal of the fertiliser subsidy in 1994/ 95, making it unaffordable to many farmers. The extremely low levels of purchasing power in Malawi, poorly developed marketing systems and limited export potential make rural livelihood diversification difficult for most of the rural poor. Hence they are caught in a maize poverty trap, unable to move beyond subsistence maize production and constantly facing the threat of food shortages.

There is evidence that food insecurity, particularly transitory food insecurity, has been getting worse in Malawi. In 2001-2003 Malawi suffered a food crisis. This was manifested in a six-fold increase in food prices, which left around 3.5 million people food insecure. The crisis was the combined result of climatic shocks, mis-management of the country's strategic grain reserve, poor crop estimates and a chaotic delayed response in terms of maize imports (Stevens et al., 2002; World Development Movement, 2002). However, the effects on the Malawian population, including starvation-related deaths, were more severe than in neighbouring countries where a similar proportion of the population had been affected. In addition, although Malawi suffered a maize production shortfall in 2000/ 2001 and 2001/2002 compared to the previous two years, production was close to the twelve year average and the decline was nothing like the production shortfall of the 1991/1992 drought year (see Fig. 1). However, compared to the early 1990 s the effects of the 2000-2003 crisis on welfare and food security were much more severe. It would seem therefore, that the Malawian population has become more vulnerable to food insecurity. Vulnerability can be seen as a function of exposure to hazard and the ability to cope with hazard (Webb and Harinarayan, 1999). Over the past decade and a half both the frequency of food security hazards in Malawi - local climatic events, HIV/AIDs, policy mistakes, price shocks - has increased whilst the ability of the population to cope with such hazards - as determined by their assets, social capital, degree of livelihood diversification - has declined. 
Table 1

Poverty lines for Malawi (at April 1998 prices)

\begin{tabular}{|c|c|c|c|c|c|}
\hline & Poverty line (MK) & Food (MK) & Non-food (MK) & Ultra (MK) & Food share of the poverty line $(\%)$ \\
\hline Southern rural & 7.76 & 6.53 & 1.23 & 4.65 & 84.1 \\
\hline Central rural & 9.27 & 7.76 & 1.51 & 5.56 & 83.7 \\
\hline Northern rural & 11.16 & 8.90 & 2.26 & 6.69 & 79.7 \\
\hline Urban & 23.38 & 16.95 & 8.90 & 15.23 & 66.8 \\
\hline National weighted average poverty line & 10.47 & - & - & - & \\
\hline
\end{tabular}

Source: ODI (2004, Table 6).

Note: $\mathrm{MK}=$ Malawi Kwacha.

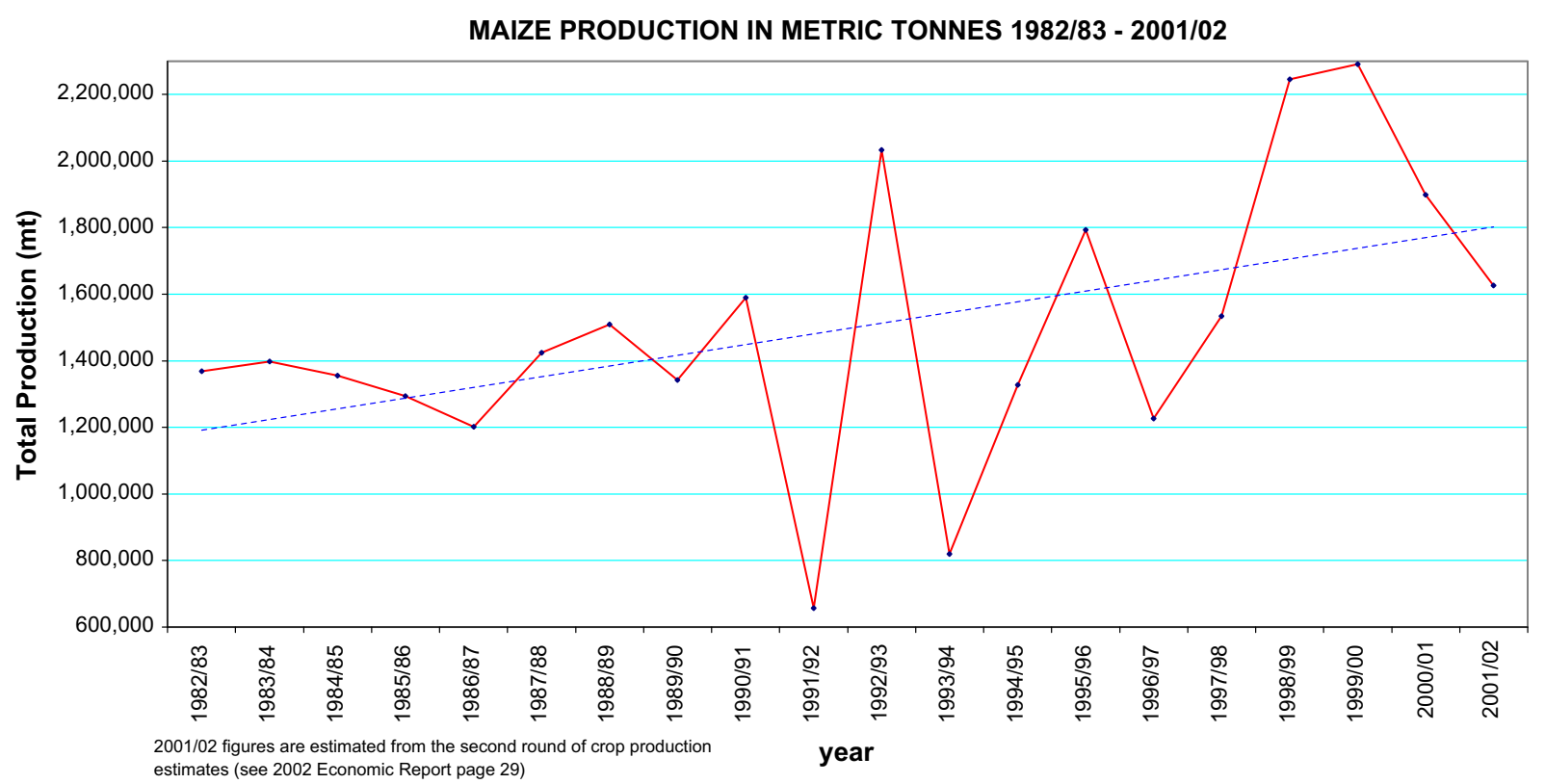

Fig. 1. Maize production in metric tonnes 1982/1983-2001/2002.

\section{Food security options for countries like Malawi}

At the level of national aggregate food security Malawi faces two options - relying on domestic production, i.e. food self-sufficiency, or relying on imports. These two sources of food security are not mutually exclusive, in that part of the country's food requirements can be domestically produced and part imported. It seems clear that over the past $10-15$ years 'Malawi has shifted from being a nationally self-sufficient producer of maize in non-drought years to being dependent on commercial food imports and foreign assistance to achieve a national food balance' (Oygard et al., 2003, p. 45). This poses a question to government and donors - should this trend be allowed to continue, perhaps even be encouraged, or should efforts be made to boost domestic food production to reverse or at least ameliorate the trend?

Still at the level of national food security, if the import route is favoured, then policies need to be in place to ensure that foreign currency is available for food imports - either by promoting exportable cash crop production or via a process of industrialisation. To the extent that foreign exchange earnings are inadequate for commercial food imports, then food aid will be required.

If domestic production is the preferred route to national food security then a variety of often complimentary policies can be employed to boost domestic food crop production. These can include non-price policies such as technology transfer to improve yields, extension work, free inputs, infrastructure development, credit schemes and market development. In addition price policies such as subsidised inputs and attractive output prices for food producers who market their crop can also be used.

Regardless of whether the emphasis is on imports or domestic production, vagaries in domestic production, in exchange rates, import and transport costs, etc., make various forms of insurance policies desirable. These usually consist of a strategic grain reserve and/or a financial reserve. Both may need to be called on if domestic production is unexpectedly low and/or if import costs are unexpectedly high. More sophisticated forms of insurance include weather insurance and commodity price hedging.

The above has briefly sketched the main policy options for achieving national aggregate food security. However, 
such an achievement is necessary but not sufficient to ensure individual and household food security. A nation may possess adequate aggregate food supplies, whether domestically produced or imported; yet chronic food insecurity may persist amongst segments of the population. Hence, policies need to be devised to ensure access to adequate food by all people at all times. A range of policies, many of them complimentary, is available to achieve this objective. Food self-sufficiency might be promoted at the household level by trying to ensure that as many households as possible meet their own subsistence food requirements. This is a difficult process which requires mainly non-price interventions such as free input delivery as with Starter Pack, extension services, improved technology and price policies such as affordable inputs and credit. Alternatively, a policy of livelihood diversification might be pursued (stressing farm and/or off-farm income sources) so as to provide individuals with purchasing power, with simultaneous market development to ensure market access to food. Functioning markets are critical to enhanced food security but many countries, particularly Malawi, have been unsuccessful in simultaneously promoting food security objectives and market development. Whatever approach to household food security is taken it needs to be complimented by some form of social safety net system for asset poor households unable, at least in the short term, to access market opportunities making them vulnerable to chronic food insecurity. Fig. 2 presents a diagrammatic representation of the above food security policy options.
A cross cutting issue in discussions of both national and individual food security strategies, which has dominated the donor-government discourse in many countries in Eastern and Southern Africa, is the relative role of the state versus the private sector in any of the above policy options. The debate between government and donors in Malawi regarding food security strategies has for years, if not for decades (Harrigan, 2003), been dominated by the issue of the relative role of government and the private sector. Arguments over the future of the small holder state marketing board ADMARC, and over the National Food Reserve Agency (NFRA) and who should manage the strategic grain reserve have diverted attention away from the more fundamental issue - how to tackle the country's extensive chronic food insecurity. A more sensible approach would be to develop a consensus around a viable food security strategy (i.e. imports, domestic production, food crop diversification, subsistence production, livelihood diversification) and then to work out the complexities of the respective roles of government and the private sector in implementing the strategy and how these roles might evolve over time.

The above outline of food security options provides us with an analytic framework to help understand the donor and government debates surrounding the free input Starter Pack programme in Malawi. On the one hand there are those donors, such as USAID, who saw the Starter Pack as a waste of money that threatened to lock Malawian small holders into a maize poverty trap. Such donors envisaged appropriate food security policies to consist of liveli-

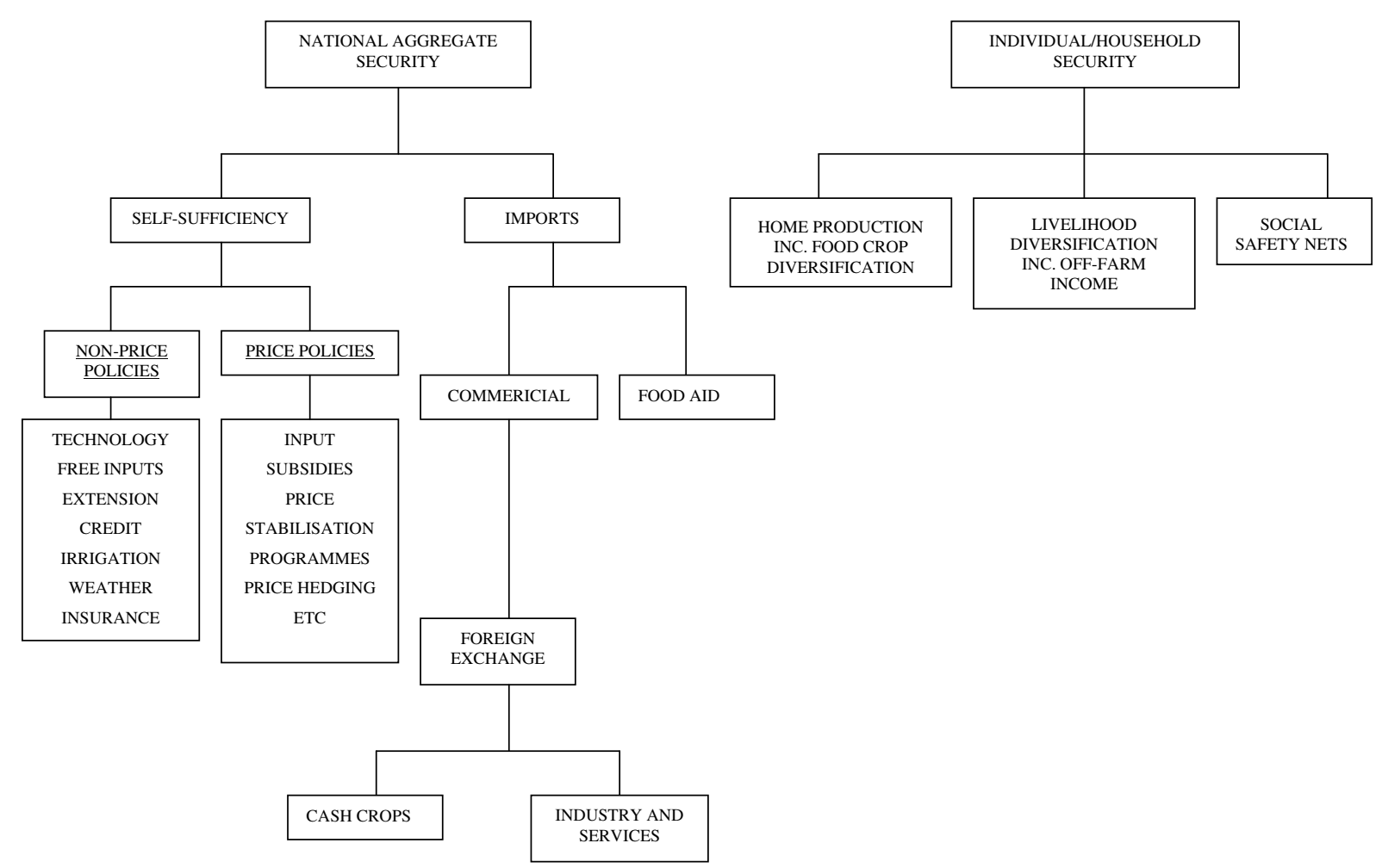

Fig. 2. Food security strategies. 
hood diversification with small holder export cash production being used to earn foreign exchange to purchase part of the country's food requirements in the form of imports. Under such a scenario Starter Pack money should be used instead to promote cash crop production and move small holders away from dependence on maize. On the other hand donors such as DFID as well as the Malawi government itself have argued that the USAID model is not a cost effective use of resources. Malawi is a landlocked country with poor domestic and regional infrastructure giving rise to a high import parity cost of maize. It has been estimated that the marginal cost of an extra tonne of maize in Malawi is US\$400 if brought in as food aid, US\$200 or more if commercially imported from neighbouring countries, US $\$ 150-$ US $\$ 150$ if grown by small holders in a good harvest year and less than US\$50 if grown by Malawian farmers making good use of Starter Pack (Levy, 2005). These marginal cost measures suggest that domestic maize production is a cost effective route to food security and that shifting resources to cash crops will have a high opportunity cost in terms of the cost of imported maize.

\section{Food security policies in Malawi since independence}

Between independence in 1964 and the late 1970s Malawi experienced rapid rates of economic growth based on an agricultural-based exported-orientated development strategy. The engine of growth was the estate sector ${ }^{2}$ exporting tobacco, tea and sugar. Life President Banda also placed national food security via self-sufficiency high on his populist political platform. This was achieved via emphasis on small holder production of maize. The strategy received strong support from the state in the form of the state marketing board ADMARC, which offered small holders subsidised maize seed and fertiliser and purchased the maize output at guaranteed pan territorial prices. ADMARC also sold the maize in the domestic market at subsidised consumer prices. The losses it made on its maize trading account were cross subsidised by profits it made by buying small holder export crops, such as tobacco, cotton and groundnuts, at producer prices well below export parity, and then exporting.

In terms of achieving national aggregate food security the post-independence policy was a success. Throughout most of the 1960s and 1970s Malawi was food self-sufficient and in many years had a surplus of maize to export to the region. However, the overall agricultural strategy was such that whilst the estate sector grew at over $17 \%$ per annum, small holder growth was less than $3 \%{ }^{3}$ Essentially, the

\footnotetext{
${ }^{2}$ In Malawi the distinction between estates and small holder farmers is based on land type not farm size. Estate producers are those who farm leasehold land whilst small holder producers are those who farm customary land.

3 The estimates of GDP and small holder growth during this period are subject to debate (Harrigan, 2001, p. 18-23) with some authors arguing that subsistence production was seriously overestimated (Kydd and Christiansen, 1982, p. 359).
}

small holder sector was used to provide cheap labour and food to the estate sector whilst small holder land was also annexed by the estates and profits made by ADMARC on small holder export crops channelled into the estates (Harrigan, 1988). Consequently, although data is sparse, it seems that during this period many small holders became increasingly impoverished - evidenced for example by the small holder labour transfer to the estates despite a $6 \%$ per annum fall in real labour earnings in the estate sector (Kydd and Christiansen, 1982). This was exacerbated by the regime's general neglect of distributional and poverty issues, with public expenditure, for example, prioritising the productive rather than the social sectors. Hence, although national aggregate food security was achieved, individual household food security was not guaranteed.

The 1980s saw a reorientation of agricultural policy in Malawi, largely under the auspices of World Bank and IMF structural adjustment and stabilisation programmes. Liberalisation in the agricultural sector initially took the form of increasing ADMARC's producer prices for small holder export crops whilst reducing the relative producer price of maize. At the same time subsidies on small holder fertiliser and seed were phased out. The objective was to remove price distortions and to increase the small holder contribution to export earnings. Despite strong objections from many in the Malawi government that such policies would lead to declining food production, the issue of national food security did not seem to be of central importance to the Washington-based multilaterals (Kydd and Hewitt, 1986, p. 357; Harrigan, 2001, p. 94-5). The pricing policy, combined with market liberalisation in the form of the closure of many ADMARC markets, did indeed lead to a national food crisis, such that by 1987 the government was forced to import MT 140,000 of maize - the highest import level since the early 1970s (Harrigan, 1988). In summary, the Government's focus on national food security at the expense of individual household security during the 1960s and 70s followed by a degree of donor neglect of food security issues during the 1980s, meant that by the early 1990s both household and national food security had become more precarious in Malawi (Chilowa, 1998; Sahn et al., 1990; Hawksley et al., 1989).

The 1990s witnesses a fairly ad hoc series of policy initiatives to boost small holder productivity and output along with a belated acknowledgement that the bias towards an increasingly inefficient estate sector needed to be dealt with. However, although increased small holder stratification and impoverishment as well as food insecurity were accepted as important issues, ${ }^{4}$ policies were implemented in the absence of a clearly articulated food security strategy.

The policies of the 1990s involved diversifying small holder income sources, in particular by removing restrictions that had prevented small holders from growing

\footnotetext{
${ }^{4}$ President Muluzi, who came to power in 1994 following the country's first multi-party elections, placed poverty alleviation high on the UDF policy agenda.
} 
lucrative crops such as burley tobacco, as well as promoting increased maize productivity via the spread of hybrid maize with a return to subsidised inputs and credit. The government was also forced, in a reactive ad hoc manner, to deal with food insecurity at the household level. The 19921993 Southern African drought reduced maize production in Malawi by over $50 \%$ (see Fig. 1) and approximately two thirds of the population registered for food assistance. In addition to food aid, the government responded to the crisis with the Drought Recovery Inputs Programme (DRIP) which involved distributing free maize seed and fertiliser to 1.3 million small holder households (Devereux, 1997). Apart from the drought years, the subsidies and free input programmes in place between the late 1980s and mid1990s resulted in a sharp increase in maize hectarage ${ }^{5}$ and the adoption of improved maize varieties, and many talked of Malawi's delayed green revolution (Smale, 1995).

Despite the drought, which clearly exacerbated the increase in poverty that was already occurring in rural Malawi, and despite the initial green revolution success, donors insisted that the government push ahead and remove the fertiliser subsidies that had been reintroduced in the late 1980s. Subsidies were dropped in 1994/1995 and this coincided with the collapse of the small holder Credit Association (SACA). ${ }^{6}$ Consequently, by the mid1990s, although there had been a temporary post-drought recovery, Malawi faced an underlying agricultural crisis. Rural livelihoods were deteriorating (Frankenberger and Luther, 2003), inequality among small holders had increased (Peters, 1996), fertiliser prices had risen twice as much as the maize producer price due to subsidy removal and devaluation of the Kwacha, input use had declined as had hybrid maize production (Orr et al., 2001). In addition, due to market liberalisation and the reduced role of ADMARC in the maize market, intra-seasonal maize consumer prices (between harvest and later in the year) were widening. This adversely affected the food security of small holder households, most of whom were net food consumers who were often forced to sell maize post-harvest at low prices to meet cash needs and then buy back latter in the year at much higher prices (Whiteside and Carr, 1997). The coping strategies used by the most vulnerable households to deal with growing food insecurity, such as ganyu labour ${ }^{7}$ and asset depletion further intensified the vicious poverty-food insecurity cycle.

\footnotetext{
5 The continued importance of maize is shown by the fact that by 1990 Malawi had the highest per capita maize consumption in the world.

${ }^{6}$ SACA collapsed partly because during the multi-party election campaign in 1994 the UDF had promised farmers that in return for their vote they would not need to repay their credit and partly because the 1992-1993 drought led to asset depletion and inability of many small holders to repay credit.

7 Ganyu labour refers to the provision of labour for families and friends, often for payment in kind at very low rates. Devereux (1999) has argued that this method of meeting food needs can often have a negative effect on longer-term food security of the ganyu labourer's household by pulling labour away from their own fields during critical times.
}

Between 1994 and 1997 further ad hoc initiatives were introduced to try to deal with growing poverty and food insecurity. In 1994-1995 the Supplementary Inputs project (SIP) was introduced by the government, DFID and Action Aid. The programme targeted around 800,000 small holder families, predominantly in southern Malawi, and provided hybrid maize seed and fertiliser as well as small amounts of cassava and sweet potato cuttings and sorghum seed. In addition, in 1995 as part of the World Bank Poverty Alleviation Programme, the Malawi Social Action Fund (MASAF) was set up to provide targeted assistance to the chronically poor. A key component of MASAF was public works programmes in food deficit areas involving self-targeting food and cash for work (Devereux, 1997). ${ }^{8}$

One of the clearest failings of the above series of ad hoc policy initiatives was that they were largely reactive. The inability to put into place proactive policies to tackle poverty and food insecurity was partly due the lack of a clear food security strategy that commanded broad support. Indeed, the situation was made worse by a lack of agreement between government, donors and NGOs. The government continued to favour national maize self-sufficiency using subsidised inputs to increase both output and productivity. Many donors, on the other hand, advocated market liberalisation and small holder income diversification via the promotion of high value exportable cash crops, especially tobacco. Some donors, such as the World Bank and USAID, pushed for rapid liberalisation and seemed implicitly to assume that diversion of land from food crops to exportable cash crops could be compensated for by maize imports, whilst other donors such as DFID and the EC advocated a slower phased liberalisation with a focus on food security implications and the need for social safety nets. NGOs and the UN agencies placed much greater emphasis on household food security via safety nets based on free inputs and food aid. However, the impact was limited due to the fact that food aid was only able to treat the symptoms not the cause of food insecurity whilst small-scale input programmes had a limited impact (Frankenberger and Luther, 2003, p. 25-26).

\section{Starter Pack and its contribution to food security}

It was in the context of the above confusion and growing evidence of a decline in soil fertility that the Starter Pack was conceived. It is clear that in many ways the DRIP and SIP programmes were the forerunner of Starter Pack. In 1996 a Maize Productivity Task Force was established to examine the technical and policy options for dealing with chronic national food shortages, and Starter Pack was one of the main recommendations. The Task Force acknowledged that Malawi was facing a crisis of declining

\footnotetext{
${ }^{8}$ The MASAF public works programme has subsequently been criticised for failing to consider the work burdens on women, and for poor targeting, including exclusion of the most vulnerable (Frankenberger and Luther, 2003, p. 27).
} 
soil fertility and maize productivity leading to national food shortage and that fertility could only be restored by the application of inorganic fertiliser. Starter Pack offered a solution in terms of "best bet" technologies for maize production which were the result of five years of research and field trials (Levy, 2005, Chapter 1). The technology consisted of providing all small holders with small packs containing semi-flint hybrid maize seed $(2 \mathrm{~kg})$, and fertiliser $(15 \mathrm{~kg})$ as well as legumes ( $1 \mathrm{~kg}$ of seed) to improve soil fertility. The pack was enough to cultivate 0.1 ha and it was estimated that it would more than double maize yields. As a result farmers would be able to produce an extra $100-150 \mathrm{~kg}$ of maize.

In terms of the food security policy options illustrated in Fig. 2, Starter Pack was clearly a policy designed to increase national food self-sufficiency via non-price interventions to boost production. It was also a statist as opposed to a free market approach. It was estimated that with universal coverage ( 2.8 million packs) it would boost domestic maize production by between MT 280-420,000 per annum, thus avoiding the need for maize imports and contributing to the maintenance of the country's strategic grain reserve. Fig. 1 shows that in the two seasons in which Starter Pack was universally distributed, maize output rose considerably with a large part of the increase attributable to the free inputs programme (see Fig. 3). Maize yields were also significantly higher in these years, although it should be noted that rainfall was also high in these years such that Starter Pack does not account for all of the improvement. Indeed, over the past ten years it is only in the production seasons in which government has intervened through universal free input delivery (1998/99, $1999 / 2000,2002 / 2003$ ) that the country has been able to produce a surplus or near surplus of maize.

Although Starter Pack focused on food self-sufficiency at the national level it also had the potential to significantly improve household food security. Firstly, by enabling each small holder household to produce an extra $100-150 \mathrm{~kg}$ of maize this provided an extra two to two-and-a-half months of maize cover for a family of six. ${ }^{9}$ The importance of this is seen by the fact that with an average small holder land holding of 0.8 ha most small holder families are unable to feed their family throughout the year from own production. As shown in Table 2 in the three months before harvest (April-June) three quarters of households are without their own maize, even in a good year. In addition, between $10 \%$ and $20 \%$ of the most chronically poor small holders are food deficit for nine months or more. Hence, an extra two to two-and-a half month's maize supply can have a major impact on household food security.

The second manner in which Starter Pack contributed to household food security was via its effect on the maize consumer price. By providing each household with several

\footnotetext{
${ }^{9}$ Based on the FAO recommendation of $180 \mathrm{~kg}$ of maize per adult per year and assuming this is halved for children.
}

month's extra maize, demand for maize in the market was reduced so dampening the intra-seasonal increase in the maize consumer price. Hence, chronically poor families who were forced to buy food were less crowded out by the better off. ${ }^{10}$ Clearly, this price reduction effect worked largely via market demand rather than supplies to the market. ${ }^{11}$

It is now widely accepted that household food security has three key dimensions: food availability, food access and food utilisation (ODI, 2004, p. 4). Starter Pack made a clear contribution to both availability and access via its output and price effects. In addition, the inclusion of legumes in the pack not only contributed to improving soil fertility, but by diversifying sources of food also contributed to improved food utilisation. It would seem, therefore, that the universal Starter Pack, the first of its kind in Malawi, offered a fresh start to food security at both the national and household level. By helping to address the pressing problem of household food insecurity it also promised to alleviate a key constraint that often prevented the chronically poor from escaping the poverty trap.

\section{Donor opposition and the evolution of Starter Pack to the Targeted Input Programme (TIP)}

Despite the above arguments, many of Malawi's key donors quickly came to view Starter Pack not as a fresh start but as a false start. The ensuing disputes both amongst the donor community and between donors and government provide a sad example of poor donor behaviour (Harrigan, 2005). Criticisms ranged from the view that: Starter Pack was undermining the development of private sector input delivery; that it suffered from operational and logistical weaknesses; that it was creating an inappropriate dependency on maize and contributing to what USAID referred to as the "maize poverty trap" (Rubey, 2003 ) and that it was a costly programme which the government could not afford. Following the scaling down of Starter Pack to the Targeted Input Programme donors also criticised TIP as being poorly targeted.

Given that Starter Pack seemed to offer a promising fresh start to food security in Malawi, and possibly for other countries in the region, it is worth assessing the basis of the donor opposition. It is important to note that in some instances donor opposition was based on a dislike of state interventionism in principle. In other instances, opposition reflected an evolution of donor views on appropriate food security strategies - this was particularly

\footnotetext{
10 The effect of poor maize output on food prices was graphically illustrated in the 2002 food crisis year where hungry season maize prices in the Central Region, for example, rose to MK 45 per $\mathrm{kg}$ compared to the norm of less than MK 15 per $\mathrm{kg}$. It was high prices rather than lack of food availability that led to hunger and starvation-related deaths in 20022003.

11 Estimates from 2000 to 2003 suggest that only $10-15 \%$ of small holders sold any maize (Levy, 2003).
} 


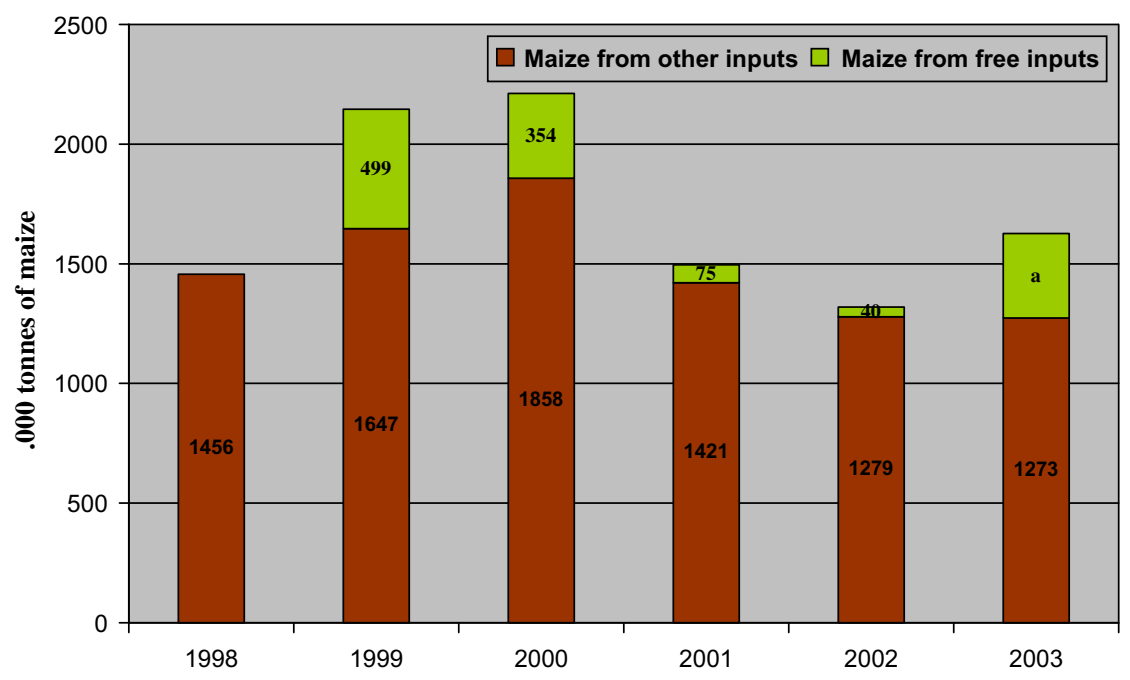

Fig. 3. Maize production (main season).

Table 2

Months of maize deficit for small holder farmers

\begin{tabular}{llll}
\hline & $\begin{array}{l}2000-2001 \\
(\% \text { of farmers })\end{array}$ & $\begin{array}{l}2001-2002 \\
(\% \text { of farmers })\end{array}$ & $\begin{array}{l}2002-2003 \\
(\% \text { of farmers })\end{array}$ \\
\hline 9 months or more & 10 & 17 & 22 \\
6 months or more & 32 & 52 & 50 \\
3 months or more & 72 & 87 & 82 \\
No deficit & 5 & 3 & 6 \\
\hline
\end{tabular}

Source: 2001, 2002 and 2003 TIP evaluation surveys.

so in the case of the EC, the lead agency in the donor community on food security issues. When Starter Pack was launched the EC, like the government, tended to focus on maize production as the route to food security and this was reflected in the first EC Food Security Programme (1997-2001). However, work on the EC's second Multi Annual Food Security Programme (MAFSP) saw a fundamental shift in the EC position towards a more holistic food security strategy, focusing on livelihood diversification and food accessibility rather than simple food production and supply. The EC strongly believed this gave it a wider poverty focus orientated not just towards small holders but also towards the vulnerable landless or near landless. ${ }^{12}$ Within this context Starter Pack came to be seen as an inhibitor of rural livelihood diversification away from maize production.

\footnotetext{
12 The new EC approach consisted of five components. (1) Increased government ownership of food security policy via the break-up of the EC Food Security Unit with staff distributed to the Ministries of Agriculture and Finance. (2) Replacing APIP (Agricultural Productivity Investment Programme) as a provider of credit in kind with an institution to provide micro credit to finance a wider range of players including those wishing to invest in micro, small and medium enterprises. (3) Increased emphasis on off-farm sources of income with the creation of a public works scheme The Employment Generation Scheme Support (EGSS). (4) Support for a wide range of NGO activities focusing on livelihood diversification. (5) A safety net programme for the severely malnourished ultra poor located outside mainstream food security programmes.
}

Donor opposition to Starter Pack on the grounds that it undermined the development of private sector input delivery was most vocally articulated by USAID, who saw Starter Pack as directly undermining its Agricultural Input Markets Development Project (AIMS). Starter Pack was centrally managed by a logistics unit and although transport, warehousing and distribution was contracted out to the private sector, USAID and other donors argued that it was larger urban based operators who benefited, which both squeezed out rural input retail outlets and diverted profits back to the urban centres. However, supporters of the programme have argued that the intention was quite the reverse - Starter Pack was not designed to displace commercial input delivery but rather to provide inputs to those who may not have bought them, giving them experience with high quality inputs in a manner that would stimulate commercial demand.

Another frequent criticism was that Starter Pack was beset by operational problems such as late pack delivery, inappropriate pack content and poor supporting extension advice. However, many of these problems arose because lack of donor financial commitment and support for the programme meant that it never became institutionalised within the government's public expenditure plans. As can be seen from Table 3 donor funding was patchy and unreliable, DFID being the only donor to offer consistent support to the programme (for which it often received harsh criticism from other donors).

The donor argument that Starter Pack created maize dependency leading to a maize poverty trap was based on the perceived need for rural livelihood diversification. It was argued that the route out of food insecurity and poverty required diversification into non-maize food crops, into cash crops and into off farm income sources. There is some evidence to support this view in that those Districts with the greatest dependence on maize had the greatest number of food insecure households during the 20012003 food crisis (Levy, 2003, reported in ODI Fig. 2). A 
Table 3

Financing of starter pack/TIP (\$US million)

\begin{tabular}{|c|c|c|c|c|c|c|c|c|c|c|}
\hline Year & GoM & DFID & WB & $\mathrm{EC}$ & Norad & IFAD & RoC & Libya & Total & GoM $\%$ \\
\hline 1998 & 14.5 & 8.2 & 1.7 & 0.7 & & & 0.5 & & 25.6 & 56 \\
\hline 1999 & 12.5 & 4.3 & 7.2 & & & 1.2 & & & 25.2 & 50 \\
\hline 2000 & 2.3 & 2.8 & & 1.5 & & & & 0.9 & 7.6 & 31 \\
\hline 2001 & 2.4 & 3.6 & & 1.2 & & & & & 7.2 & 33 \\
\hline 2002 & 1.3 & 9.9 & & & 2.2 & & & & 13.4 & 9.5 \\
\hline 2003 & 1.2 & 10.9 & & & & & & & 12.1 & 10 \\
\hline Total & 34.2 & 39.8 & 8.9 & 3.5 & 2.2 & 1.2 & 0.5 & 0.8 & 91.1 & \\
\hline
\end{tabular}

Note: GoM = Government of Malawi; WB = World Bank; RoC = Republic of China.

Source: Starter Pack logistics unit records.

more general criticism of promoting household maize production via hybrids is that Malawi is beset by small and declining farm size (Kutengule, 2000) and declining soil fertility. This has led many to argue that hybrid maize production cannot solve the food security problem for large numbers of families holding less than 0.5 ha of land. At best it can provide an extra two to three months food cover above the three to four months provided by tradition maize varieties (Devereux, 1997). Consequently encouraging small holders to focus on maize production via free input programmes inhibits them from moving into higher value crops and activities and so condemns them to perpetual poverty. The validity of this critique depends upon the viability of a food security model that does not rely on household food self-sufficiency and may even require abandoning the national self-sufficiency approach in favour of imports. The extent to which Malawi is ready for such an approach will be discussed below.

The donor critique that Starter Pack was costly and unaffordable seldom involved consideration of the cost of alternative strategies to improve household food security. Estimates suggest that in the absence of intervention Malawi faced a food deficit of between 500,000 and 600,000 MT per annum in the early 2000s (Levy, 2005, Chapter 2). If Starter Pack is to be rejected as too costly an intervention, then cheaper policies to ensure food security are necessary. The comparisons, however, are not favourable. The universal Starter Pack had a fixed cost of around \$20-25 million per annum. By contrast rough estimates calculated in Levy (2005) Chapter 8 suggest that a general fertiliser subsidy would have cost at least as much and would also benefit estate farmers, which include commercial farmers and medium sized graduated small holders. Required maize imports in the absence of the universal Starter Pack would have cost \$70-100 million, food aid around $\$ 100$ million and welfare transfers to the $30 \%$ of chronically poor households around $\$ 107$ million. Indeed, the costs of failing to achieve food security, not just in terms of financial costs, but also in terms of the resulting macroeconomic instability, were clearly illustrated in the 2001-2003 food crisis. However, these costings are not static, and the recent growth in cheap maize imports in the form of cross border trade from Mozambique suggests that the pursuit of national food self-sufficiency through pro- grammes such as Starter Pack, may perhaps no longer be the most viable route to food security, a point which will be taken up in Section 'Support to input access and the future of Malawi's food security policies'.

\section{The evolution of Starter Pack to the Targeted Input Programme (TIP)}

Table 3 shows that in 1998 and 1999 the government contributed half of the total cost of the universal Starter Pack programme - partly via the use of the government fertiliser stock. However, from 2000 onwards, government's contribution fell steadily from over $50 \%$ to under $10 \%$. This was due to IMF pressure to restrict the government's contribution to under $\$ 2.5$ million as part of the fiscal austerity programme. The higher share contributed by donors such as the EC, gave the donors more leverage over the form of the programme, which in 2000 was scaled down to TIP. Most government officials seem to agree that it was largely due to donor pressure that Starter Pack became TIP. Although initial objections to the programme had largely focused around fiscal cost, within a few years donors were articulating a wide range of objections to the original programme. These objections coincided with an evolution of donor food security policies towards a more holistic livelihoods approach as well as an elevation of the social safety net programme in Malawi. Hence, donors were willing to endorse a scaled down free inputs programme and to recast it in the light, not of a production enhancing technological transfer, but as one of many targeted social safety nets, albeit not necessarily the most effective. However, this compromised the original aims of the programme:

'Alas, this small holder productivity programme was hijacked by the donor determination to transform it into a safety net programme, targeted to the poorest...The shift to safety net also muted the focus on productivity. Composite maize with lower gearing (maize/nitrogen) was substituted for the hybrids...The African solution was distorted substantially as filtered through donor lenses - targeting replaced universal coverage; an untested system was substituted for a proven one.'

(Member of original Maize Productivity Task Force). 
Table 4

Malawi's free inputs programmes

\begin{tabular}{lll}
\hline Date & Programme & \\
\hline $1992-1993$ & Drought Recovery Inputs Project & \\
$1994-1995$ & Supplementary Inputs Project & 1.3 million \\
$1995-1996$ & Supplementary Inputs Project & 800,000 \\
$1998-1999$ and 1999-2000 & Starter Pack & 660,000 \\
$2000-2001$ & Targeted Input Programme & 2.8 million \\
$2001-2002$ & Targeted Input Programme & 1.5 million \\
$2002-2003$ & Extended Targeted Input Programme \\
$2003-2004$ & Extended Targeted Input Programme \\
\hline
\end{tabular}

After the donor decision to scale down Starter Pack was made, the programme in the form of TIP, went through a number of iterations. In 2000 agreement was reached to scale down the programme in steps as other interventions under the Malawi National Safety Net Strategy were gradually introduced. In 2000-2001 1.5 million packs were distributed and in 2001-2002 1 million. The selection of beneficiaries was based on a community targeting process using vulnerability criteria derived as part of the Safety Net work. However, it is now generally agreed that this targeting process was both inefficient and divisive (Levy and Barahona, 2002). ${ }^{13}$ Following the food crisis of early 2002 , the programme was scaled up in 2002-2003 to 2 million donor funded packs and 800,000 government funded packs in what was referred to as the "Extended TIP". The improved food situation in 2003 meant that the number of packs was again reduced to 1.7 million. Table 4 provides a summary of Malawi's free input distribution schemes since 1992, including the various iterations of Starter Pack/TIP. It is beyond the scope of this paper to discuss the extent to which the scaling down of Starter Pack contributed to the 2002 food crisis. It is now accepted that the crisis had a wide range of diverse causes (Stevens et al., 2002; World Development Movement, 2002), but undoubtedly, the move to TIP played a part.

\section{Support to input access and the future of Malawi's food security policies}

A near universal TIP was implemented at the last minute for 2004-2005, but this was largely due to political factors. ${ }^{14}$ Subsequently, the debate about Starter Pack in Malawi has been eclipsed by the debate about fertiliser subsidies, which have been in place for the past two seasons. Political parties have been competing to promise voters different types of subsidy programmes whilst donors initially started off with varying degrees of opposition to subsidies

\footnotetext{
${ }^{13}$ Unfairly, donors subsequently criticised TIP as an inefficient targeted social safety net programme. However, the original Starter Pack was never intended to be a targeted social safety net and only became so under donor pressure.

14 During the 2004 election campaign, key politicians promised a return to fertiliser subsidies. The 2004-2005 TIP was hurriedly and belatedly put together as a cheaper, but politically palatable, alternative.
}

which reflected their earlier positions on Starter Pack. More recently however, as Government has proved determined to press ahead with subsidies, donor positions have started to soften and the Malawi subsidy programme is attracting considerable interest, as did the earlier Starter Pack programme.

This softening of positions reflects a new donor pragmatism. However, there still exists considerable division of opinion regarding the longer-term approach to food security that should be adopted in terms of the options illustrated in Fig. 2.

Given that the original universal Starter Pack and more recently the fertiliser subsidies have made a substantial contribution towards both national and household food security in Malawi, how can we reconcile the diversity of often strong views about ongoing support to input supply for maize production in Malawi? The strongest and most compelling objection to the continuation of such support is that it will inhibit the process of rural livelihood diversification and as such condemn many small holders to a perpetual maize poverty trap. This line of argument, also associated with advocacy of a policy of rural livelihood diversification away from maize production and greater reliance on imports from regional countries such as Mozambique and South Africa by the private sector and a scaling down of the strategic grain reserve, is well represented by the following quote from Rubey (2003):

'Recognise that the single-minded pursuit of a policy of maize self-sufficiency is counter-productive and effectively condemns many Malawians to perpetual poverty. Malawi is likely going to be a net importer of maize in the future, but this need not be viewed as a failure...Past analysis has suggested that the costs of maintaining a national grain reserve that would be large enough to make up for a significant shortfall are simply too high and the potential benefits too low.' (Rubey, 2003, p. 3-4).

However, it would be wrong to characterise the Malawi government's enthusiasm for ongoing support to input supply for maize production as tantamount to a denial of the need for livelihood diversification. Both government and external observers acknowledge that, in addition to raising maize output via the introduction of high yielding fertilised varieties, four other approaches to rural poverty and food security also require serious consideration (Devereux, 1997; Orr and Orr, 2001). First food security needs to 
be improved by diversifying food crops towards more drought resistant and less nutrient demanding crops such as cassava, sweet potatoes, groundnuts and beans and it is clear that such a diversification trend is already underway in Malawi. ${ }^{15}$ Secondly, cash crop production should be promoted to improve food security by increasing household purchasing power. In Malawi this entails the promotion of traditional small holder crops such as tobacco and cotton, as well as new high value crops such as spices, fruit and vegetables and soybean. Thirdly, there is a need to promote the growth in non-farm income as the route to livelihood diversification and improved food access (Orr et al., 2001). This would involve the promotion of micro and small-scale enterprise such as beer brewing, food processing, furniture making. ${ }^{16}$ Finally, especially if food production is scaled up to more productive larger farmers, income earning opportunities in the form of wage labour on such farms offers another route to both increasing national food production and increasing purchasing power at the household level.

Despite acceptance by all parties on the need for rural livelihood diversification, the differences of opinion on the role of support to input supply for maize production in such a process can perhaps be explained by different time horizons and perception of risk. Many donors articulate an essentially long-term vision of food security in Malawi, involving diversified food production, increased small holder cash crop production and increase in off-farm income with well developed private markets enabling individuals to utilise their increased purchasing power to access food. In such an environment, they see no need for the handout of free inputs except perhaps as a very limited form of safety net for the most vulnerable. Most in government share this vision, but are acutely aware that it is a long-term vision, which will need to be preceded by a very tricky, protracted and risky transition phase. Government officials are extremely concerned about the food security risks during the transition and see support to input supply for maize production as having a role to play as a production enhancing intervention.

One aspect of Government risk aversion is the reluctance to see maize imports as a major component of food security. Malawian politicians and government officials have long been wary of a strategy that puts too much emphasis on food imports. A decade and a half of civil war in Mozambique cutting off landlocked Malawi's most direct access to the sea has engendered an almost siege mentality, which still persists despite the ending of hostili-

\footnotetext{
$\overline{15}$ Between 1990/91 and 1998/99 small holder production of millet, pulses, beans, potatoes and cassava increased from MT 465,000 to MT 3,046,000 (Harrigan, 2003 Fig. 3).

${ }^{16}$ There is strong evidence that such diversification is occurring rapidly, albeit from a small base. Between 1992 and 1999 the number of new micro-enterprises increased fivefold from 20,000 to 100,000 (Orr and Orr, 2002).
}

ties in her neighbour. Throughout the 1980s and early 1990s large strategic grain reserves and fertiliser buffer stocks, partially financed by the EC, were a reflection of this mentality. Even now, as a landlocked country with poor transport infrastructure in neighbouring countries, the viability of extensive reliance on bulky food imports remains in doubt. The food crisis of 2001-2003 graphically illustrated the logistical problems of estimating and correctly timing food imports and dealing with transport bottlenecks as well as the difficult interactions between government imports and private sector importers. In addition the events of 2001/2002 showed that as a relatively small country in the sub-region Malawi is acutely exposed whenever a regional food shortage occurs since its larger neighbours Mozambique, Zambia, Zimbabwe - have first call over food imports by virtue of their greater size and purchasing power and better connections with South Africa and overseas markets.

However, the situation regarding maize imports has evolved rapidly in the past few years. There is evidence of significant growth in quantities of informal maize trade particularly between Northern Mozambique and Southern Malawi at low prices (Whiteside et al., 2003) ${ }^{17}$ In the trade years 2001/2002 and 2002/2003 between a third and a half of Malawi's maize imports were informal and in 2002/2003 alone it is estimated that MT 223,000 was informally imported from Mozambique. If this trend continues there may be a strong argument that part of Malawi's national food security strategy should rely on imports. If this is so, the justification for large-scale support to input supply to boost domestic production becomes much weaker. A pre-requisite for greater reliance on imports however, is a well functioning and highly efficient strategic grain reserve to ensure national food security in years of regional production shortfalls and possibly a financial interest earning reserve to enable purchases on world food markets. At present, there is still debate about the size of Malawi's strategic grain reserve and the manner in which it should be operated by the newly formed commercial National Food Reserve Agency.

Even if national food security is achieved via greater reliance on imports, the issue of ensuring household food security remains. A greater reliance on cheap maize imports could potentially go hand in hand with the promotion of rural livelihood diversification away from maize production. But the issue of risk and time horizons arises again. The process of diversification will be slow and many of the most vulnerable may well not be able to participate. In addition, it assumes well functioning and non-exploitative food markets such that access to food at affordable prices is guaranteed. The key question, therefore, is will

\footnotetext{
${ }^{17}$ Low prices are due to the fact that average maize prices are lower in Mozambique than in Malawi due to the former's extensive methods of production without the use of fertiliser. This is possible due to Mozambique's much lower population density and subsequent better soil fertility.
} 
Malawi's nascent private sector be able to guarantee imports and domestic food markets? If not, what role should the government play in the transition process and how can this be done in such a way that it does not inhibit private sector development?

Finally, if the strategy of greater reliance on maize imports and rural livelihood diversification is adopted as a long term objective it is absolutely essential that appropriate social safety nets are in place to protect the vulnerable. It is generally accepted that support to input supply for maize production is not the best way to offer a food security safety net and that in terms of targeting and efficiency, public works schemes offer a better alternative. However, given the magnitudes of food insecurity and poverty outlined in Section 'Food insecurity and poverty in Malawi', existing public works schemes will need to be massively scaled up and other interventions designed for those such as the elderly and the sick who are unable to participate in such schemes.

On the other hand, if increased reliance on food imports is deemed too risky, then the issue of boosting the productivity of domestic food production, especially maize production is critical. The experience would suggest that a universal Starter Pack or fertiliser subsidy offers a viable and cost effective method of improving national food self-sufficiency whilst also having a strong positive effect on household food security.

\section{Lessons from Malawi's Starter Pack/TIP experience}

Malawi is typical of many countries in sub-Saharan Africa, with an agricultural sector dominated by poor, land scarce and capital scarce small holders suffering from food insecurity. Hence its experience with Starter Pack is of relevance to other countries in the region.

Starter Pack was a successful production intervention that helped achieve both national and household food self-sufficiency in Malawi. At the time when it was introduced promoting national maize production seemed a cheaper alternative than relying on maize imports. This situation now seems to be changing and it is possible that in the future the most sensible strategy for Malawi will be to place greater reliance on food imports whilst promoting the process of rural livelihood diversification. However, the price of imported food remains critical to such a strategy, and in the event of cheap imports from Mozambique proving temporary, the implication is that government would need to fund a costly subsidy to keep the price of imported food affordable. Under such a scenario, support to input supply for maize production again looks attractive.

If a universal Starter Pack is in future considered either in Malawi or elsewhere, it is important to be realistic in terms of what Starter Packs can and cannot achieve. If properly implemented, they can improve food security at all levels. However, although Starter Pack, by helping to address the issue of household food security, may provide a platform on which to build rural growth strategies, Star- ter Pack itself should not be seen as a growth policy. ${ }^{18}$ At best, therefore, Starter Pack is a pre-requisite for growth if domestic food production is seen as the route to food security.

Likewise, in terms of poverty reduction, Starter Pack is not a panacea for poverty but rather a pre-requisite for poverty reduction. It helps alleviate one key symptom of poverty, namely food insecurity, but it cannot reduce poverty in the sense of having a direct lasting impact. Nevertheless, its indirect impact may be significant - investments in health, education and rural development are more effective when people are not chronically or acutely malnourished. The implication is that if boosting domestic food production via Starter Pack is to be a key part of an ongoing national food security strategy it needs to be complemented by other longer-term programmes to address poverty and boost rural growth. As such policies start to produce a positive impact it may then be possible to consider an exit from Starter Pack.

Other low-income agrarian countries can learn much from Malawi's experience with Starter Pack. Firstly, if a universal free input programme is to be implemented it needs to be clearly located within an overall national food security strategy. The Malawian experience shows that the latter is not static - as external circumstances change, e.g. the cost of food imports, the appropriateness of the various strategies outlined in Fig. 2 may likewise change. It is important therefore not to get "locked in" to a particular programme. Secondly, it is important to be realistic in terms of what a Starter Pack programme can and cannot achieve and in light of this to ensure that it is part of a holistic development strategy that recognised the links between food insecurity, poverty and low growth.

The conditions that made Starter Pack an appropriate programme for Malawi in 1998 indicate the type of country which may wish to emulate the policy. These conditions have been outlined by Levy (2005): the staple food crop is maize; soil fertility is low resulting in chronic underproduction of food; food imports are costly, e.g. for landlocked countries; and poverty is widespread and deep such that few can afford to purchase commercial inputs.

The discussion of Starter Pack in Malawi has also raised some broader issues concerning food security strategies in landlocked countries such as Malawi and the respective roles of the state and the private sector. A strategy of domestic food production using instruments such as Starter Pack may not seem the most logical when scarce

\footnotetext{
18 When Starter Pack was initially conceived it was seen as part of a rural growth strategy. It was hoped that the Starter Pack technology would allow many farmers to become surplus maize producers and make profits as commercial farmers. Hence it was only seen as a "starter" in that once commercialisation had occurred farmers would no longer need free inputs but would be able to afford them from commercial suppliers. However, subsequent large increases in input prices meant that commercial maize growing is clearly not viable for Malawian small holders even with optimum yields (Van Donge et al., 2001) and Starter Pack can no longer be seen as an important mechanism to stimulate rural growth.
} 
resources could be used to produce higher value export cash crops and the foreign exchange earnings used to import part of the countries food requirements. However, such a strategy involves a long term vision of livelihood diversification with farmers producing cash cops and relying on a well functioning marketing system to access food imports. Markets in countries like Malawi are far from well developed and indeed the policies that governments introduce in the interim to ensure food security often hamper private sector market development. It is in the crucial transition stage away from state dominated maize production towards more diversified market based livelihoods that programmes such as Starter Pack may well have a role to play as long as there are clear exit strategies and programme operation does not unnecessarily undermine market development.

\section{References}

Chilowa, W., 1998. The impact of agricultural liberalization on food security in Malawi. Food Policy.

Devereux, S., 1997. Household food security in Malawi. IDS Discussion Paper No. 362, December, Brighton, Sussex.

Devereux, S., 1999. Making Less Last Longer: Informal Safety Nets in Malawi. IDS Discussion Paper No. 373, Brighton, Sussex.

FFSSA, 2004. Achieving Food Security in Southern Africa: Policy Issues and Options, Synthesis Paper, Consultation Draft, Forum for Food Security in Southern Africa, Overseas Development Institute, London, $<$ http://www.odi.org.uk/Food-Security-Forum/docs/FFSSA_synthesis consultation.pdf $>$.

Frankenberger, T., Luther, K., 2003. Review of regional food security and nutrition surveillance systems in Southern Africa, CARE SWARMU.

Government of Malawi., 2004. Situation Analysis for Food Insecurity and Malnutrition in Malawi. GoM Mimeo: Lilongwe.

Harrigan, J., 1988. Malawi: The impact of pricing policy on small holder agriculture 1971-1988. Development Policy Review 6, 415-433.

Harrigan, J., 2001. From dictatorship to democracy: Economic policy in Malawi 1964-2000. Ashgate, Aldershot.

Harrigan, J., 2003. U-turns and full circles: Two decades of agricultural reform in Malawi 1964-2000. World Development 31 (5), 847-863.

Harrigan, J., 2005. Donor policies on food security and starter pack, part 3, In: Levy, S. (Ed.). Starter Packs: A Strategy to Fight Hunger in Developing and Transition Countries, CAB International, Wallingford.

Hawksley, E., Kalua, B., Kandoole, B., 1989. The Impact of Economic Recovery Programs on Small holder Farmers and the Rural Poor in Sub-Saharan Africa: Malawi Country Study. IFAD, Rome.

Kutengule, M. 2000. Farm and non-farm sources of income: Rural livelihood diversification in Malawi. Ph.D. thesis, School of Development Studies, University of East Anglia, United Kingdom.

Kydd, J., Christiansen, R., 1982. Structural change in Malawi since independence: consequences of a development strategy based on large scale agriculture. World Development 10 (5), 355-375.
Kydd, J., Hewitt, A., 1986. The effectiveness of structural adjustment lending: initial evidence from malawi. World Development 24 (3), $347-$ 365 .

Levy, S., 2003. Starter packs and hunger crises: a briefing for policy makers on food security in Malawi, Key findings from the Evaluation of Starter Pack/Targeted Inputs Programme (TIP).

Levy, S. (Ed.), 2005. Starter Packs: A Strategy to Fight Hunger in Developing and Transition Countries, CAB International, Wallingford.

Levy, S., Barahona, C., 2002. 2000-2001 Targeted Inputs Programme (TIP): Main Report of the Monitoring and Evaluation Programme, Report for GoM Ministry of Agriculture and DFID, September, Lilongwe.

Overseas Development Institute (ODI) (2004), Food Security Options in Malawi: Good Neighbours make Good Friends? Country Food Security Options paper Number 2, Forum for Food Security in Southern Africa, ODI: London.

Orr, A., Orr, S., 2001. Changing Livelihoods in Malawi's Rural South: A Synthesis and Interpretation. Report to DFID Malawi. Lilongwe: Kadale Consultants, April.

Orr, A., Orr, S., 2002. Agriculture and Micro-enterprise in Malawi's Rural South, ODI, Agriculture Research and Extension Network, Paper No. 119.

Orr, A., Mwale, B., Saiti, S., 2001. Market liberalisation, household food security and the rural poor in Malawi. The European Journal of Development Research 13 (1), 47-69.

Oygard, R., Garcia, R., Guttormsen, A., Kachule, R., Mwanaumo, A., Mwanawina, I., Sjaastad, E., Wik Marao,. K., Bonnerjee, A., Braithwaite, J., Carvalho, S., Ezemenari, K., Graham, C., Thompson, A. (2003). The Maze of Maize: Improving input and output market access for poor small holders in Southern Africa region, the experience of Zambia and Malawi. Agricultural University of Norway, Department of Economics and Resource Management, Report No. 26.

Peters, P., 1996. Failed Magic or Social Context? Market Liberalisation and the Rural Poor in Malawi. Harvard Institute for International Development.

Rubey, L., 2003. Malawi's Food Crisis: Causes and Consequences. USAID, Lilongwe.

Sahn, D., Arulpragasam, J., Merid, L., 1990. Policy Reform and Poverty in Malawi: A Survey of a Decade of Experience. Cornell Food and Nutrition Policy Program, Monograph 7, December.

Smale, M., 1995. Maize is Life: Malawi's Delayed Green Revolution. World Development 23 (5), 819-831.

Stevens, C., Devreux, S., Kennan, J., 2002. The Malawi Famine of 2002: More Questions than Answers. IDS, Brighton, Sussex.

Van Donge, J, Chivwaile, M., Kapondamgaga, Mgemezulu, O., Sangore, N., Thawani, E., 2001. 2001-2002 TIP: Markets and Livelihood Security in Malawi.

Webb, P., Harinarayan, A., 1999. A Measure of Uncertainty: The Nature of Vulnerability and its Relationship to Disasters, Disasters.

Whiteside, M., Carr, S., 1997. Services and policies needed to support sustainable small holder agriculture in Malawi, Report for Environment and Development Consultancy LTD, London, April 1997.

Whiteside, M., Chuzo, P., Maro, M., Saiti, D., Schouten, M.-J., 2003. Enhancing the Role of Informal Maize Imports in Malawi Food Security, A consultancy report for DFID.

World Development Movement. 2002. Structural damage: The causes and consequences of Malawi's food crisis. World Development Movement, London. 